\title{
A Thiol Inhibitor Produced by Aspergillus niger
}

\author{
By JOHN M. WALKER* AND STEVEN C. CHAPLIN \\ Department of Biological Sciences, Hatfield Polytechnic, Hatfield, Herts AL10 9AB, U.K.
}

(Received 15 July 1982; revised 23 August 1982)

A low molecular weight inhibitor of the thiol proteases papain and bromelain has been identified and partially purified from the culture filtrates of Aspergillus niger. Further studies have shown that this inhibitor reacts with compounds containing a free thiol group and as such it is capable of inhibiting other enzymes that contain a functional thiol group at their active site.

\section{INTRODUCTION}

In recent years analysis of the culture filtrates of actinomycetes has resulted in the identification of a number of relatively low molecular weight protease inhibitors, such as leupeptin (Aoyagi et al., 1969), antipain (Suda et al., 1972), chymostatin (Umezawa et al., 1970a) and pepstatin (Umezawa et al., 1970b).

Newly identified protease inhibitors have a number of obvious uses in research including their use as ligands for the affinity chromatography of proteases, in the study of the active site of enzymes and their application as inhibitors of degradation during the isolation of cellular proteins. Additionally, since many disease states are mediated by the presence of proteolytic activity, the therapeutic control of which would be highly advantageous to the patient, some such inhibitors may well be eventually developed as drugs (Barrett, 1980). The general principle of using specific enzyme inhibitors as drugs is, of course, well established.

As part of a search for further proteolytic enzyme inhibitors produced by micro-organisms we have identified an inhibitor of thiol proteases in culture filtrates of Aspergillus niger. Further investigations have shown the filtrates to inhibit other enzymes (in addition to proteolytic enzymes) that contain a functional thiol group at their active sites. These observations are reported here.

\section{METHODS}

Growth. Aspergillus niger (Hatfield Polytechnic Culture Collection, no. F8) was grown by shake culture (150 r.p.m., 11 flasks) in $500 \mathrm{ml}$ batches of malt extract broth $\left(1 \%\right.$, w/v Oxoid) at $25^{\circ} \mathrm{C}$. The initial inoculum was $50 \mathrm{ml}$ of an $A$. niger culture that had just reached stationary phase. Typically, this initial inoculum was prepared by spore inoculation (from a slope) of $100 \mathrm{ml}$ malt extract broth, followed by growth (shaking) at $25^{\circ} \mathrm{C}$ for $60 \mathrm{~h}$. For growth measurements, samples $(40 \mathrm{ml})$ were removed from the large scale culture at 12 hourly intervals, filtered under vacuum $(0.22 \mu \mathrm{m}$, Millipore), and then washed with water $(5 \times 50 \mathrm{ml})$. The resultant pellet was removed from the filter, heated to $105^{\circ} \mathrm{C}$ for $20 \mathrm{~h}$, allowed to cool, and then weighed.

Gel filtration of culture filtrates. Large scale $(500 \mathrm{ml})$ cultures were filtered $(0 \cdot 22 \mu \mathrm{m}$, Millipore) after $84-96 \mathrm{~h}$ growth. The filtrates were divided into $100 \mathrm{ml}$ lots and rotary evaporated to dryness. Each sample was dissolved in ammonium bicarbonate solution $(10 \mathrm{mM}, 5 \mathrm{ml})$ and passed through a column of Sephadex G-15 $(2.4 \times 40 \mathrm{~cm}$, flow rate $\left.60 \mathrm{ml} \mathrm{h}^{-1}\right)$ equilibrated in the same buffer. Eluted fractions $(10 \mathrm{ml})$ were monitored by their absorbance at 230 $\mathrm{nm}(100 \mu \mathrm{l}$ samples were diluted to $3 \mathrm{ml}$ with water before reading). Each tube was assayed for inhibitory activity by using the $\alpha$-glucosidase assay (see below). Tubes showing inhibitory activity were pooled, rotary evaporated to dryness and then re-dissolved in $10 \mathrm{ml}$ water. These solutions were then used for all inhibitor studies.

Enzyme inhibition studies. The ability of a solution to inhibit an enzyme was determined by comparing the activity of the enzyme when pre-incubated with inhibitor solution with the activity of the enzyme when pre-

Abbreviations: PNPG, p-nitrophenyl- $\alpha$-D-glucopyranoside; LDH, lactate dehydrogenase. 
incubated alone in buffer. Pepsin, bromelain and papain were all assayed by using the casein digest method described by Umezawa (1972). The buffers used were: $0.1 \mathrm{~m}$-phosphate, pH 6.8 (bromelain assay), $50 \mathrm{~mm}$-borate, $\mathrm{pH} 7 \cdot 3$ (papain assay) and $20 \mathrm{~mm}-\mathrm{HCl} / \mathrm{KCl}, \mathrm{pH} 2 \cdot 0$ (pepsin assay). The amount of enzyme used per assay, and the source of enzyme was as follows: pepsin (Sigma, ex-hog stomach mucosa, $5 \mu \mathrm{g}$ of enzyme per assay); papain (Sigma, ex-papaya latex, $100 \mu \mathrm{g}$ per assay); bromelain (Sigma, ex-pineapple stem, $100 \mu \mathrm{g}$ per assay). Trypsin (Sigma, ex-bovine pancreas) was assayed by using the benzoyl arginine ethyl ester hydrolysis method described by Schwert \& Takenaka (1955), and carboxypeptidase A (Sigma, ex-bovine pancreas) was assayed by using hippurylphenylalanine as described by Ryan et al. (1974). $\alpha$-Glucosidase (Sigma, ex-bakers yeast) was assayed by following the hydrolysis of $p$-nitrophenyl- $\alpha$-D-glucopyranoside (PNPG). $\alpha$-Glucosidase (100 $\left.\mu \mathrm{l}, 1.0 \mathrm{mg} \mathrm{ml}^{-1}\right)$ was incubated with buffer $\left(3.0 \mathrm{ml}, 100 \mathrm{~mm}\right.$-phosphate, $\left.\mathrm{pH} 6.8,25^{\circ} \mathrm{C}\right)$ either with or without inhibitor solution $(100 \mu \mathrm{l})$ at $25^{\circ} \mathrm{C}$ for $20 \mathrm{~min}$. PNPG (100 $\mu 1,10 \mathrm{mg} \mathrm{ml}^{-1}$ in phosphate buffer) was then added and the increase in absorbance at $410 \mathrm{~nm}$ monitored. Lactate dehydrogenase (LDH, Sigma, ex-rabbit muscle) activity was also measured spectrophotometrically. Buffer $(3.0 \mathrm{ml}, 200 \mathrm{mM}$-Tris $/ \mathrm{HCl}, \mathrm{pH} \mathrm{7.3})$ and enzyme $\left(100 \mu \mathrm{l}, 0.5 \mathrm{units}^{-1}\right)$ were incubated at $25^{\circ} \mathrm{C}$ for $10 \mathrm{~min}$ with or without inhibitor solution $(100 \mu \mathrm{l})$. Sodium pyruvate $(100 \mu \mathrm{l}, 30 \mathrm{~mm})$ and NADH $(100 \mu \mathrm{l}, 6 \mathrm{mM})$ were then added and the decrease in absorbance at $340 \mathrm{~nm}$ monitored. Malt extract broth alone was shown to have no effect on any of the enzyme assays studied. For each assay the pH of the inhibitor solution was adjusted to that of the assay buffer. The results of the inhibition studies are shown in Table 1. All figures are the mean of duplicate experiments.

Treatment of inhibitor with proteolytic enzymes. To inhibitor solution $(100 \mu \mathrm{l})$ was added $100 \mu \mathrm{l}$ buffer containing

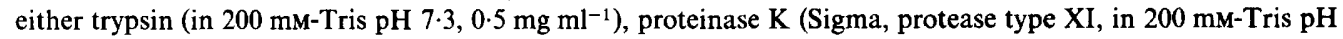
$7 \cdot 3,0.5 \mathrm{mg} \mathrm{ml}^{-1}$ ) or pronase (Sigma, protease type XIV, in $100 \mathrm{~mm}$-phosphate buffer, $\mathrm{pH} 6 \cdot 8,0.2 \mathrm{mg} \mathrm{ml}^{-1}$ ). Solutions were incubated at $37^{\circ} \mathrm{C}$ for $1 \mathrm{~h}$ and then heated to $100^{\circ} \mathrm{C}$ for $20 \mathrm{~min}$ to destroy enzyme activity. Suitable controls were prepared containing either no enzyme or no inhibitor, and each solution was assayed for inhibitory activity using the $\alpha$-glucosidase assay.

\section{RESULTS AND DISCUSSION}

Initial observations with the culture filtrates from $A$. niger showed that papain (a thiol protease) was totally inhibited by filtrates from $A$. niger cultures (Table 1), whereas other classes of proteolytic enzymes (trypsin, a serine protease; pepsin, an acid protease; and carboxypeptidase A, a metallo-enzyme) were unaffected. Further studies showed that bromelain (another thiol protease) was also completely inhibited by the filtrates (Table 1), suggesting that the inhibitor might prove to be a general inhibitor of thiol proteases. Later studies (see below) have shown that other enzymes containing a functional thiol group at the active site (e.g. $\alpha$ glucosidase and lactate dehydrogenase) are equally inhibited. Because of the ease and accuracy of the $\alpha$-glucosidase assay, compared to the more time consuming and less informative casein digest method, the $\alpha$-glucosidase assay was chosen as the general method for monitoring and characterizing the inhibitor.

The production of the inhibitor with respect to the growth of $A$. niger is shown in Fig. 1. The inhibitor was first detected at early- to mid-exponential phase, rapidly reaching a maximum level at mid-exponential phase, the level only decreasing slightly as growth reached the stationary phase. During growth the $\mathrm{pH}$ of cultures routinely dropped from $5 \cdot 1$ to reach $\mathrm{pH} 2 \cdot 0$ at stationary phase. In general, inhibition was only produced in culture filtrates when the $\mathrm{pH}$ dropped below $3 \cdot 2$.

Initial fractionation of the culture filtrates by gel filtration on Sephadex G-15 showed the inhibitory activity to elute midway between the totally included and excluded volumes, suggesting a molecular weight for the inhibitor in the range 500-1000. Boiling the inhibitor fraction at $\mathrm{pH} 6.8$ for 15 min resulted in no loss of inhibiting activity, nor was this activity lost by repeated freezing/thawing cycles. Both these observations tend to support a low molecular weight for the inhibitor. All further work described here was carried out on pooled fractions recovered from the gel filtration column. These partially purified fractions were also shown to contain the papain and bromelain inhibitory action observed in the original culture filtrate (Table 1).

Incubation periods of greater than $30 \mathrm{~min}$ were generally necessary to achieve complete inhibition of $\alpha$-glucosidase. This led us to investigate the time course of inhibition, the results of which are shown in Fig. 2. The time-dependent inhibition of $\alpha$-glucosidase suggests an 


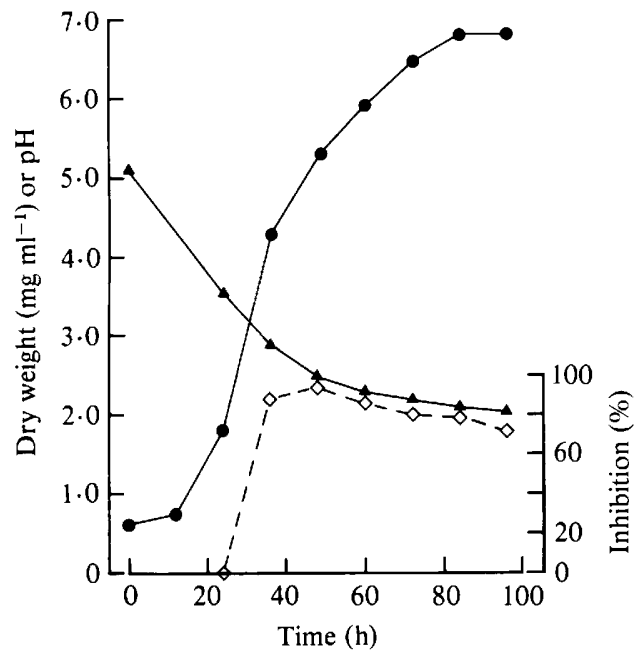

Fig. 1. Growth (dry weight) of $A$. niger; $\boldsymbol{\Delta}$, change in $\mathrm{pH}$ of the culture medium during growth; and $\diamond$, production of inhibitor in relation to growth. Inhibition was measured using $1: 10$ dilutions of the culture medium against the assay for $\alpha$-glucosidase activity.

\section{Table 1. Effect of inhibitor solutions on different enzymes}

\section{Enzyme activity \\ (absorbance or change in absorbance*)}

Inhibitor

Assay system

Plus inhibitor No inhibitor

Culture filtrate

G-15 column fraction

Papain (casein assay)

Culture filtrate

G-15 column fraction

G-15 column fraction

G-15 column fraction pre-incubated with $30 \mathrm{~mm}$ - $\beta$-mercaptoethanol

G-15 column fraction pre-incubated with $10 \mathrm{~mm}$-cysteine

G-15 column fraction

Inhibited enzyme incubated for $30 \mathrm{~min}$ with $30 \mathrm{~mm}-\beta$-mercaptoethanol

Inhibited enzyme incubated for $30 \mathrm{~min}$ with $80 \mathrm{~mm}$-cysteine

G-15 column fraction

Boiled G-15 column fraction

Pronase treated G-15 column fraction

Pronase control sample

Proteinase K treated G-15 column

fraction

Proteinase $\mathbf{K}$ control sample

Trypsin treated G-15 column fraction

Trypsin control sample

G-15 column fraction $(100 \mu \mathrm{l})$

G-15 column fraction $(200 \mu \mathrm{l})$
Bromelain (casein assay)

$0 \cdot 004\}$

$0.003\}$

$0 \cdot 400$

$0.016\}$

$0.030\}$

$0 \cdot 940$

$\alpha$-Glucosidase assay

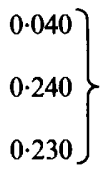

$\alpha$-Glucosidase assay

$\left.\begin{array}{c}0.030 \\ 0.030 \\ 0.030\end{array}\right\}$

$\alpha$-Glucosidase assay

\begin{tabular}{|c|}
\hline 0.040 \\
\hline 0.040 \\
\hline 0.040 \\
\hline 0.190 \\
\hline 0.030 \\
\hline $\begin{array}{l}0.030 \\
0.150 \dagger\end{array}$ \\
\hline 0.025 \\
\hline \\
\hline
\end{tabular}

LDH assay
$0.035\}$

$0.020\}$
$0 \cdot 240$

* $A_{280}$ for the casein digest, $\Delta A_{340}$ for LDH and $\Delta A_{410}$ for $\alpha$-glucosidase.

+ Reduced rate attributed to residual proteolytic activity degrading $\alpha$-glucosidase. 


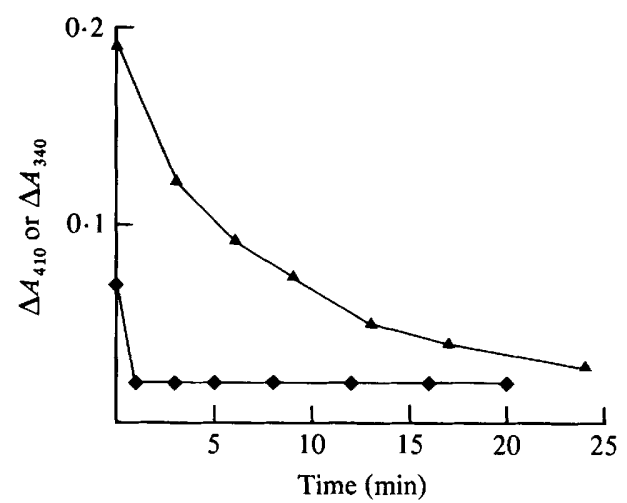

Fig. 2. Effects of different pre-incubation times of inhibitor with enzyme on the activities of $\boldsymbol{\Delta}$, $\alpha$-glucosidase and $\gamma$, lactate dehydrogenase.

irreversible inhibition. Evidence for irreversible binding of inhibitor to $\alpha$-glucosidase was provided by the observations that inhibited enzyme could not be reactivated by incubation for $30 \mathrm{~min}$ in the presence of high levels of thiol agents ( $80 \mathrm{mM}$-cysteine, $30 \mathrm{mM}-\beta$-mercaptoethanol) (Table 1). In an attempt to see if the inhibitor would react with thiol groups in general, inhibitor solutions were incubated in the presence of both mercaptoethanol $(10 \mathrm{mM})$ and cysteine $(30 \mathrm{mM})$ for $20 \mathrm{~min}$. (These thiol reagents had no effect on the activity of $\alpha$-glucosidase). Following this treatment the solutions were unable to inhibit the $\alpha$-glucosidase assay, suggesting that the inhibitor is a general thiol-reactive compound and can be 'mopped-up' by thiol groups (Table 1). Inhibitor solutions treated with pronase, proteinase $\mathbf{K}$ and trypsin all retained their inhibitory activity which suggests that the inhibitor is probably not a polypeptide (Table 1).

A further enzyme type containing a functional thiol group at the active site was also investigated. Again this enzyme could be inhibited, the amount of inhibition depending on the amount of solution added (Table 1). However, unlike the inhibition of $\alpha$-glucosidase the inhibition was rapid and not time dependent (Fig. 2). Since high levels of thiol agents ( $30 \mathrm{mM}-\beta$ mercaptoethanol and $80 \mathrm{mM}$-cysteine) alone had no effect on the activities of either LDH or $\alpha$ glucosidase, reduction in activity of both $\alpha$-glucosidase and LDH would appear to be due to reaction at the active site rather than to denaturation of the enzymes by the reduction of disulphide bridges.

We conclude from the above observations that $A$. niger produces a compound capable of reacting with free thiol groups and consequently this compound can inhibit different classes of enzymes that have a functional thiol group at their active sites. The data indicate that the inhibitor is not similar to the specific peptide protease inhibitors previously isolated from actinomycetes (Umezawa, 1972).

\section{REFERENCES}

Aoyagi, T., Takeuchi, A., Matsuzoki, K., KawaMURA, S., KONDO, M. \& UMEZAWA, H. (1969). Leupeptins, new protease inhibitors from actinomycetes. Journal of Antibiotics 22, 283-287.

BARReTt, A. J. (1980). Protease inhibitors: potential drugs? In Enzyme Inhibitors as Drugs, pp. 219-229. Edited by M. Sandler. London: Macmillan.

Ryan, C. A., Hass, G. M. \& KuHN, R. W. (1974). Purification and properties of a carboxypeptidase inhibitor from potatoes. Journal of Biological Chemistry 249, 5495-5499.

Schwert, G. W. \& Takenaka, Y. (1955). The determination of trypsin and chymotrypsin. Biochimica et biophysica acta 16, 570-575.
Suda, H., Aoyagi, T., Hamada, M., Takeuchi, T. \& UmeZaWA, H. (1972). Antipain, a new protease inhibitor isolated from actinomycetes. Journal of Antibiotics 25, 263-266.

UMEZAWA, H. (1972). Enzyme Inhibitors of Microbial Origin. London: University Park Press.

Umezawa, H., Aoyagi, T., Morishima, T., Hamada, M. \& TAKeUCHI, T. (1970a). Chymostatin, a new chymotrypsins inhibitor produced by actinomycetes. Journal of Antibiotics 23, 425-429.

Umezawa, H., Aoyagi, T., Morishima, M., Hamada, M. \& TAKeUCHI, T. (1970b). Pepstatin, a new pepsin inhibitor produced by actinomycetes. Journal of Antibiotics 23, 259-265. 